\title{
KAJIAN SEJARAH DAN PERKEMBANGAN TEORI EFEK MEDIA
}

\author{
Musfialdy ${ }^{1}$ \\ Ine Anggraini
}

\begin{abstract}
Media is one of the important needs for the community, but the media has an effect on the community both directly and indirectly. In Media Effects Theory three paradigms are used by the media to find out the effects of these media. The first paradigm, called the powerful effects paradigm (Direct Effects Models), the media is said to have enormous power so that members of the isolated and anonymous audience of this mass audience will surrender immediately. The second paradigm is the minimalist effect or the limited effects paradigm (Limited Effects Models), the media seen in audience control over selectivity. The third paradigm of cumulative effects (Cumulative Effects Models), the community has too much potential for media in limited exposure. At present, the research on the theory of media effects has developed sufficiently to the extent of several specific sub-areas of research
\end{abstract}

Key word: Theory of media effects

\begin{abstract}
Abstrak
Media merupakan salah satu kebutuhan penting bagi masyarakat, namun media memiliki efek terdadap masyarakat baik secara langsung maupun tidak. Dalam Teori Efek Media tiga paradigma yang digunakan media untuk mengetahui efek dari media tersebut. Paradigma pertama, yang disebut paradigma efek kuat (Direct Effects Models), media dikatakan memiliki kekuatan luar biasa besar sehingga anggota khalayak yang terisolasi dan anonim dari khalayak massa ini akan menyerah segera. Paradigma kedua efek minimalis atau paradigma efek terbatas (Limited Effects Models), media terlihat dalam control khalayak atas selektivitas. Paradigma ketiga efek kumulatif (Cumulative Effects Models), masyarakat terlalu berpotensi terhadap media dalam paparan pada terbatas. Saat ini penelitin teori efek media telah cukup berkembang sampai pada tingkatan beberapa sub area khusus penelitian.
\end{abstract}

Kata Kunci : Teori Efek Media

\section{Pendahuluan}

Media merupakan salah satu kebutuhan penting bagi masyarakat. Media hadir dalam kehidupan kita sehari hari. Media saat ini sudah menjadi kebutuhan pokok dalam kehidupan masyarakat Setiap hari kita selalu bersentuhan dan membutuhkan media. Pada saat manusia sedih dan gembira, saat susah dan senang, siang dan malam media menjadi sesuatu yang dibutuhkan dan diperlukan oleh manusia. Dapat dikatakan bahwa hampir setiap kegiatan dan permasalahan dalam masyarakat melibatkan media.

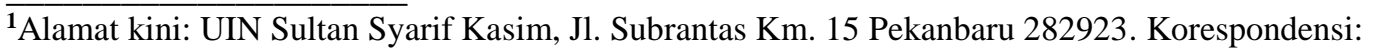
musfialdy@uin-suska.ac.id

${ }^{2}$ Alamat kini: Universitas Subang, Jl. RA Kartini Km. 3 Subang. Korespondensi: ineanggraini@unsub.ac.id
} 
Perkembangan media memberi kemudahan kepada kita untuk berinterksi dan berkomunikasi bahkan mengkonsumsi informasi. Media memberikan harapan yang baik bersamaan dengan kemajuan teknologi dan industri. Melalui media, kita dapat bertukar informasi, pendapat, ide, serta wacana yang menciptakan perkembangan masyarakat untuk terus berjalan. Perkembangan media yang terjadi saat ini dapat memberikan posisi bagi tersedianya ruang pada segenap anggota masyarakat untuk berinteraksi satu sama lain. Bahkan dengan perkembangan media tersebut, maka semakin berkembang pula masyarakat menuju tercipta masyarakat yang demokrasi. Kemajuan media lebih untuk menyediakan ruang bagi publik untuk berinteraksi.

Menurut McLuhan media sangat berpengaruh pada masyarakat. "media melingkupi setiap tindakan di dalam masyarakat" (West \& Tuner 2010, 140). Media memberikan kita informasi, hiburan, pendidikan dan interaksi di dalam masyarakat. Pada saat kita masih dalam kandungan - music yang diperdengarkan kepada bayi saat dalam kandungan - sampai kita meninggal media sangat melekat pada diri manusia. Ketika kita bangun -alarm pagi berbunyi membangunkan kita, membaca buku, menonton televisi, update status di smartphone serta kegiatan lain- media sudah ada bahkan dipergunakan oleh kita. Setiap hari kita tidak dapat melarikan diri dari media dalam kehidupan kita. Bahkan pada masyarakat modern, media merupakan sesuatu hal yang penting di dalam kehidupan sosial. Artinya tidak ada masalah individu dan sosial yang tidak melibatkan media.

Disamping tingkat kebutuhan kita akan media cukup besar, media memiliki efek lain yang ditimbulkanya. Dalam teori media dan komunikasi massa, dijelaskan bahwa hampir sebagian orang terkena efek dari media massa. "Para peneliti merasa bahwa media memiliki efek yang sangat langsung dan tidak langsung pada audiens". (Littlejohn \& Foss, 2009, 623). Media dalam hal ini media massa dianggap memiliki pengaruh besar tehadap kehidupan dalam masyarakat. Pengaruh inilah yang kemudian diteliti sejaumana efek dari media tersebut.

\section{Metode Penelitian}

Pada kajian analisis perkembangan teori media, peneliti mengunakan studi pustaka. Studi kepustakaan adalah kegiatan untuk menghimpun informasi yang relevan dengan topik atau masalah yang menjadi obyek penelitian. Informasi tersebut dapat diperoleh dari buku-buku, karya ilmiah, tesis, disertasi, ensiklopedia, internet, dan sumbersumber lain. Dengan melakukan studi kepustakaan, peneliti dapat memanfaatkan semua informasi dan pemikiran-pemikiran yang relevan dengan penelitiannya. Peneliti mengunakan survey terhadap literatureliterature tentang perkembangan efek media selama ini. Penelitian studi pustaka terhadap efek media sudah lama dilakukan oleh ilmuan. Banyak ilmuan komunikasi, psikologi dan ilmuan social lainya mempelajari efek media selama lebih seabad.

Sejarah penelitian efek media ini dimulai dengan penelitian tentang surat kabar beberapa abad yang lalu. Diawali dengan penemuan kertas tahun 105 oleh Ts'ai Lung di Cina. Kemudian penemuan mesin cetak tahun 1400-1468 oleh Johanes Guteenberg di Jerman. Tahun 1622 diterbitkan koran (surat kabar harian) pertama yakni Weekly News di London, Inggris. Selanjutnya penelitian media mengarah pada film -produksi film pertama dibuat pada akhir 1800-an dan pada awal 1900-an. Perkembangan radio dimana stasiun radio resmi pertama mulai beroperasi pada 2 November 1920. Serta penemuan televisiTahun 1947 televise swasta pertama CBS 
melangsungkan siaran pertama. Terakhir internet dimana penemuanya dimulai tahun 1969 oleh Militer AS yang menciptakan ARPAnet untuk menghubungkan kontraktor dan periset.

$$
\text { Para awalnya peneliti hanya }
$$
menyikapi efek media dari Teori StimulusRespon dari Melvin Defluer, dan Teori Opini Umum dari Walter Lippman. Namun sering dengan pesatnya perkembangan teknologi media, penelitian media pada tahun 1920-an mulai diseriuskan dengan penelitian terhadap efek media. Berdasarkan alasan tersebut maka lahirlah Teori Efek Media. Dalam Teori Efek Media tiga paradigma yang digunakan media untuk mengetahui efek dari media tersebut. Paradigma pertama, yang disebut paradigma efek kuat (Direct Effects Models), Paradigma kedua efek minimalis atau paradigma efek terbatas (Limited Effects Models), Paradigma ketiga efek kumulatif (Cumulative Effects Models)

\section{Paradigma pertama efek kuat (Direct Effects Models)}

Paradigma penelitian pertama dimulai dari efek kuat media. Penelitian tentang efek kuat (Direct Effects Models) dimulai tahun 1920-an di USA. Model ini didasari oleh model stimulus-respons (S-R) dari teori stimulus-respons Melvin DeFleur dan Rokeach. Dalam teori ini para psikolog berpandangan bahwa khalayak massa yang pesimis. Media dikatakan memiliki kekuatan luar biasa besar sehingga anggota khalayak yang terisolasi dan anonim dari khalayak massa ini akan menyerah segera. (Littlejohn \& Foss, 2009, 632). Asumsi lainya dampak komuniksi massa yang kuat kurang lebih universal dari pada semua audience (Servin, Werner J. 2005, 314).

Model ini diawali dengan munculnya media penyiaran massa seperti radio, film, dan televisi. Efek yang di timbulkan oleh media penyiaran tadi mengalahkan khalayak massa yang mengkonsumsi media tersebut. Sebagai contoh pada 30 Oktober 1938 Orson Welles produser radio, memproduksi dan membuat narasi radio tentang sebuah cerita penyerangan alien ke bumi. Naskah ini adaptasi dari cerita fiksi ilmiah "War of the Worlds" dan dibuat oleh Mercury Theatre of the Air. Siaran ini mengakibatkan 1 juta penduduk Amerika mengalami histeria massal. Orang-orang yang mendengar siaran tersebut, mengira bangsa USA benar-benar diserang oleh makhlukmakhluk dari Mars. Efek dari hysteria massa yang di akibatkan siaran radio tersebut menurut peneliti saat ini timbulah teori jarum hipodermik. (Hypodermic Needle Theory)

\section{Teori Jarum Hipodermik. ( Hypodermic Needle Theory)}

Harold Lasswell

Pada mulanya Teori Jarum Hipodermik ini dikemukan oleh Harold Lasswell pada tahun 1920-an. Teori Jarum Hipodermik (Hypodermic Needle) atau biasa disebut juga teori peluru (Bullet Theory), memprediksikan efek-efek komunikasi massa yang kuat dan kurang lebih universal pada semua khalayak (Servin, Werner, 2005, 314). Asumsi dasar teori ini adalah pertama, media massa secara langsung, cepat, dan mempunyai efek yang kuat atas mass khalayak. Kedua, media mssa digambarkan lebih pintar dan lebih segalanya dari khalayak. Ketiga, Khalayak dianggap sebagai kumpulan orang yang homogen dan pasif sehingga apapun yang diberikan oleh media dapat diterima begitu saja dan menjadi budaya baru dalam kehidupan mereka.

Menurut Elihu Katz dalam buku The Diffusion of New Ideas and Practices tahun 1963 ada beberapa aspek yang menarik dalam teori jarum hipodermik.

1. Model massa memiliki kekuatan yang luar biasa, sanggup menginjeksi secara 
mendalam ide-ide kedalam pikiran orang yang tidak berdaya.

2. Audience massa dianggap seperti atom-atom yang terpisah satu sama lain yang tidak saling berhubungan dan hanya berhubungan dengan media.

3. Apabial individu-individu dalam audience massa memiliki pendapat sama dalam suatu persoalan, hal ini bukan karena mereka berhubungan atau berkelompok satu dengan lainya. Tetapi mereka memperoleh pesan yang sama dari satu media.

Teori ini muncul lagi pada tahun 1950-an dimana teori ini dikemukan oleh Wilbur Scramm dengan teori peluru. Namun teori ini kemudian tidak dipakai lagi kerana audience massa yang menjadi efek dari media tidak pasif.

\section{Paradigma Kedua Efek Minimalis atau Efek Terbatas (Limited Effects Models)}

Paradigma efek terbatas merupakan pemikiran yang memandang media terlihat dalam control khalayak atas selektivitas. Menurut paradigma ini kita pada saat mengkonsumsi media dapat selektif menerima pesan-pesan media. Khalayak juga -pada saat diterpa media- dapat secara selektif memperhatikan elemen-elemen tertentu dari pesan-pesan media. Khalayak dapat memilih cara menerima atau menafsirkan pesan, dan khalayak dapat memilih apa yang akan disimpan dan diingat, atau dipelajari dari media.

Pada paradigma efek terbatas juga memandang terjadi perubahan pengaruh dari media ke khalayak. Perubahan tersebut terjadi pada persepsi efek media yang kuat menjadi satu di mana media dilihat hanya memiliki pengaruh minimal pada penonton. Perubahan ini merupakan hasil dari penelitian yang dilakukan oleh Paul Lazafeid, Bernard Berelson, dan Hazel Gaudet. Penelitian yang dilakukan Universitas Columbia pada tahun 1940 menemukan bagaimana hubungan sosial di antara orang-orang dan pengaruh individu orang-orang dalam jaringan aliran komunikasi serta atribut pribadi lainnya memiliki efek terbatas pada pesan yang dimediasi. (Littlejohn \& Foss, 2009, 633). Selanjutnya Lazarsfeld dan rekan-rekannya mengembangkan gagasan aliran dua langkah pesan media, sebuah proses di mana para pemimpin opini memainkan peran yang sangat penting. Singkatnya, karakteristik pribadi dan sosial individu dan kelompok membuat orang memilih komunikasi massa yang mencerminkan kepercayaan mereka sendiri. Media hanya digunakan sebagai penguat

\section{Teori Uses \& Grativication}

Elihu Katz, Jay G. Blumler, dan Michael Gurevitch

Teori Uses and Gratifications merupakan perpanjangan dari teori kebutuhan dan motivasi yang dikembangkan Abraham Maslow pada tahun 1970 yang mengemukakan bahwa manusia secara aktif mencari pemuasan kebutuhannya mulai lebih konkrit sampai kepada hal-hal yang bersifat abstrak.

Sebagaimana dijelaskan dalam model efek terbatas, teori uses dan grativikasi memandang pengaruh dari sumber-sumber media dan efek pesan ke penggunaan khalayak dari konten media. Menurut Elihu Katz, Jay G. Blumler, dan Michael Gurevitch dalam Uses and gratifications Research (Katz, 1973, 37) dalam teori uses and gratification, sistem media, institusi sosial, dan audiens saling membutuhkan dan memiliki tujuan yang dituju serta sumber daya untuk menawarkan yang lain. Sebagai contoh, sistem media bergantung pada sistem sosial yang lebih besar untuk struktur dan legitimasi dan pada khalayak 
sehingga mereka dapat menghasilkan pendapatan iklan. Pada gilirannya, media menawarkan penyebaran informasi untuk sistem sosial yang lebih besar dan hiburan dan informasi untuk khalayak ramai. Ini menyoroti kekuatan dan efek media terhadap kehidupan kita sehari-hari. (Littlejohn \& Foss, 2009, 633) Menurut Katz, Teori Uses and Gratification didasarkan pada lima asumsi:

(1) Khalayak termotivasi dan bertujuan dalam perilaku komunikasi mereka;

(2) Khalayak secara aktif memilih dan menggunakan media untuk memenuhi kebutuhan atau keinginan yang dirasakan;

(3) Khalayak dipengaruhi oleh faktor sosial dan psikologis ketika memilih di antara alternatif komunikasi;

(4) Media harus bersaing dengan bentuk komunikasi lain untuk mendapatkan perhatian, pemilihan, dan penggunaan; dan

(5) Khalayak dapat mengartikulasikan alasan mereka menggunakan media.

Elihu Katz, seorang profesor emeritus sosiologi dan komunikasi di The Hebrew University of Jerusalem, mencoba memperkenalkan logika yang berbeda mencegah disintegrasi pemikiran. Menurut Katz dalam memandang pengaruh dari sumber-sumber media dan efek pesan para peneliti mengubah pertanyaan yang digunakan untuk menghasilkan penelitian terhadap efek media. Alih-alih bertanya, "Apa yang dilakukan media terhadap orang-orang?" Katz membalik pertanyaan untuk bertanya, "Apa yang dilakukan orang dengan media?" (Em Griffin, 2019, 347)

Perkembangan penelitian Use and Gratification yang terbaru dilakukan oleh Alan Rubin pada tahun 1981. Alan Rubin seorang sarjana Komunikasi menghasilkan tipologinya tentang motivasi orang menonton televisi.
Rubin mengklaim bahwa tipologinya penjelasankan yang diberikan orang untuk konsumsi media mereka, dan ini sekaligus menjawab pertanyaan Katz "Apa yang dilakukan orang dengan media?".

Delapan motivasi Rubin dapat menjelaskan sebagian besar penjelasan yang diberikan orang mengapa mereka menonton televisi. (Alan M. Rubin, 2009, pp. 165-184.) Tipologi Rubin itu antara lain :

- Melewati waktu. (Passing tim) Pertimbangkan ruang tunggu di kantor dokter. Alasan utama untuk menonton TV adalah sekadar melewatkan waktu sampai Anda dipanggil untuk membuat janji temu.

- Persahabatan. (Companionship)

Ketika penggemar olahraga berkumpul untuk menonton pertandingan besar di layar kecil, beberapa penggemar ada di sana terutama untuk kesempatan berkumpul dengan teman-teman. Menonton pertandingan adalah hal yang sekunder.

- Melarikan diri. (Escape.) Alih-alih berfokus pada makalah yang menyebabkan kecemasan karena dalam dua minggu, seorang mahasiswa mungkin hanya menyalakan tabung untuk menghindari tekanan.

- Kenikmatan. (Enjoyment) Banyak yang melaporkan bahwa alasan utama mereka menonton acara TV adalah karena mereka merasa seluruh pengalaman itu menyenangkan. Ini mungkin motivasi paling dasar untuk mengkonsumsi media apa pun.

- Interaksi sosial. (Social interaction) Menonton TV memberikan dasar untuk terhubung dengan orang lain. Jika saya memastikan untuk 
menonton episode terakhir dari acara seperti Lost, saya mungkin menemukan bahwa saya memiliki lebih banyak kesempatan untuk memulai percakapan dengan orang lain yang melihat pertunjukan.

- Relaksasi. (Relaxation) Setelah bekerja seharian, banyak orang melaporkan bahwa mereka merasa menonton TV menjadi santai. Saat ini, banyak rumah tangga memiliki setidaknya satu kamar tidur dengan satu set TV. Orang-orang kadangkadang melaporkan bahwa menonton TV membuat mereka rileks sehingga mereka sulit tidur dengan cara lain.

- Informasi. (Information) Pecandu berita melaporkan bahwa menonton TV adalah tentang mengikuti informasi terbaru hari itu. Jika mereka tidak bisa menonton TV selama beberapa hari, mereka melaporkan merasa tidak nyaman dengan informasi yang mereka tahu telah mereka lewatkan.

- Kegembiraan. (Excitement) Kadangkadang konsumen media mengejar rasa kegembiraan yang intens. Ini bisa menjadi salah satu alasan mengapa kekerasan media adalah pokok hiburan TV.Konflik dan kekerasan menimbulkan perasaan senang yang bisa disamai oleh beberapa alat dramatis lainnya.

\section{Teori Dependensi Media}

\section{Sandra Ball-Rokeach dan Melvin DeFleur}

Teori Dependensi Media seperti juga teori Uses and Gratification adalah teori yang memandang khalayak sebagai sebuah bagian yang berperan aktif dalam proses komunikasi. Bahkan sebagian ahli memandang teori dependensi merupakan teori yang meneruskan konsep teori teori uses and gratifications yang digagas oleh Elihu Katz, Jay Blumler, dan Michael Gurevitch (1970an).

Teori dependensi media adalah sebuah teori yang dibangun dan dikembangkan oleh Sandra Ball-Rokeach dan Melvin DeFleur pada tahun 1975. Dalam artikelnya " $A$ Dependency Model or Mass-Media Effects". Sandra Ball-Rokeach Sandra Ball-Rokeach, Profesor dan Dekan Asosiasi untuk urusan fakultas di Sekolah Komunikasi Annenberg di University of California dan Melvin DeFleur DeFleur menerima gelar Ph.D. dalam psikologi sosial dari University of Washington. Mereka menjelaskan perbedaan efek media massa terhadap individu dan pengaruh media massa terhadap masyarakat. Teori dependensi media sering juga disebut teori ketergantungan sistem media (media system dependency theory) adalah teori yang berdasarkan gagasan bahwa semakin orang tergantung pada media massa untuk memenuhi kebutuhannya maka peran media massa dalam hidup seseorang dipandang menjadi sangat penting dan karena itu media massa akan memiliki pengaruh yang besar terhadap orang tersebut. Tingkatan ketergantungan media dipengaruhi oleh, kapasitas media, stabilitas sosial, kebutuhan individu, sifat psikologis individu.

Menurut teori dependensi media, media sadar akan kemampuannya menciptakan hubungan ketergantungan dengan khalayak sasaran dan menggunakan kekuatannya untuk mencapai tujuan. Hubungan ketergantungan ini dibentuk melalui empat tahapan, yaitu :

- Individu tertarik pada media yang menawarkan berbagai konten yang dapat memenuhi kebutuhan mereka tentang pemahaman, informasi, dan hiburan.

- Hubungan ketergantungan dimulai dengan intensitas yang berbeda. Semakin tinggi intensitasnya maka akan semakin kuat 
rangsangan kognitif dan afektif. Rangsangan kognitif berfungsi untuk meningkatkan dan mempertahankan tingkat perhatian individu sedangkan rangsangan afektif berfungsi untuk meningkatkan tingkat kepuasan individu.

- Kedua rangsangan ini kemudian mengaktifkan tingkat keterlibatan yang lebih tinggi yang memungkinkan pemrosesan dan penghafalan informasi.

- Keterlibatan yang besar memungkinkan semakin meningkatnya efek media pada individu di tingkat kognitif, afektif, dan perilaku dalam jangka panjang. (Mohd. Rafiq, 2012, 10)

Model hubungan masyarakat dan media menurut Teori Dependensi Media

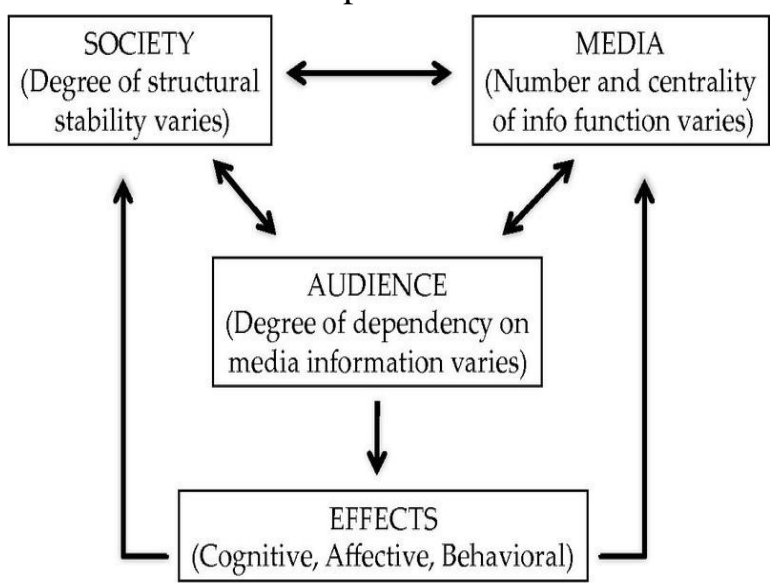

Sumber: Ball-Rokeach \& DeFleur (1975)

Secara ringkas kajian terhadap efek tersebut dapat dirumuskan sebagai berikut:

Pertama, Efek Kognitif; yaitu menciptakan atau menghilangkan ambiguitas, pembentukan sikap, agenda-setting, perluasan sistem keyakinan masyarakat, penegasan/penjelasan nilai-nilai; efek kognitif merupakan akibat yang timbul pada diri komunikan yang sifatnya informatif bagi dirinya.

Kedua, Efek Afektif; efek ini kadarnya lebih tinggi daripada efek kognitif. Tujuan dari komunikasi massa dalam hal ini bukan sekedar memberitahu khalayak tentang sesuatu, tetapi lebih dari itu, khalayak diharapkan dapat turut merasakan perasaan iba, terharu, gembira, sedih, marah, takut dan sebagainya

Ketiga, Efek Behavioral, mengaktifkan atau menggerakkan atau meredakan, pembentukan isu tertentu atau menyelesaikannya, enjangkau atau menyediakan strategi untuk suatu ktivitas serta menyebabkan perilaku dermawan. Efek behavioral merupakan akibat yang timbul pada diri khalayak dalam bentuk perilaku, tindakan atau kegiatan. (Melvin DeFleur dan Sandra Ball Rokeach 1975; 261-263)

\section{Paradigma ketiga efek kumulatif (Cumulative Effects Models)}

Paradigma ketiga merupakan paradigma yang didasari oleh metode-metode ilmiah yang jelas contohnya metode penelitian yang mengunakan laboratorium serta pendekatan peneltian multimetode. Paradima ini muncul atas dasar pandangan tentang efek yang lebih kuat. Asumsi utama dari modelmodel efek komulatif ini adalah terlalu kuatnya potensi audiens terhadap media untuk paparan pada terbatas melalui penyampaian tema dan pesan yang konsisten dan berulangulang.

\section{Teori Kultivasi}

George Gerbner

Teori ini dikemukakan oleh George Gerbner, mantan Dekan dari Fakultas (Sekolah Tinggi) Komunikasi Annenberg Universitas Pennsylvania, yang juga pendiri Cultural Environment Movement. Teori Kultifasi merupakan penelitian Gerbner terhadap perilaku penonton televisi yang dikaitkan dengan materi berbagai program televisi yang ada di Amerika Serikat. Teori Kultivasi (Cultivation Theory) merupakan salah satu teori yang muncul atas dasar pandangan tentang efek yang lebih kuat. Teori Kultivasi adalah teori yang mencoba menjelaskan 
keterkaitan antara media komunikasi (dalam hal ini televisi) dengan keyakinan serta sikap tentang dunia (tindak kekerasan).

Lebih jelasnya, Gabner dalam teori ini menyatakan bahwa melalui paparan televisi yang berulang-ulang dan berat, orang mulai memandang dunia sama dengan dunia televisi. (Littlejohn \& Foss, 2009, 634) Asumsi Teori Kultivasi pertama Televisi merupakan suatu kekuatan yang secara dominan dapat mempengaruhi masyarakat modern. Kekuatan tersebut berasal dari kemampuan televisi melalui berbagai simbol untuk memberikan berbagai gambaran yang terlihat nyata dan penting seperti sebuah kehidupan sehari-hari.

Asumsi kedua menyatakan bahwa penonton yang telah menjadi pecandu (penonton berat/heavy viewers) televisi membangun keyakinan yang berlebihan bahwa "dunia itu sangat menakutkan" . Hal tersebut disebabkan keyakinan mereka bahwa "apa yang mereka lihat di televisi" yang cenderung banyak menyajikan acara kekerasan adalah "apa yang mereka yakini terjadi juga dalam kehidupan sehari-hari”.

Asumsi ketiga kekerasan menurut Gerbner merupakan cara yang paling sederhana dan paling murah untuk menunjukkan bagaimana seseorang berjuang untuk mempertahankan hidupnya. Asumsi keempat, televisi memberikan pelajaran berharga bagi para penontonnya tentang berbagai 'kenyataan hidup', yang cenderung dipenuhi berbagai tindakan kekerasan. (Little John \& Foss 2009, 635)

Teori Kultivasi menjelaskan bahwa bahwa ada 2 (dua) tipe penonton televisi yang mempunyai karakteristik saling bertentangan/bertolak belakang, pertama para pecandu/penonton fanatik (heavy viewers) adalah mereka yang menonton televisi lebih dari 4(empat) jam setiap harinya. Kelompok penonton ini sering juga disebut sebagai khalayak 'the television type". Kelompok pecandu/penonton fanatik (heavy viewers) memiliki sikap antara lain:

1. Mereka yang memilih melibatkan diri dengan kekerasan yaitu mereka yang pada akhirnya terlibat dan menjadi bagian dari berbagai peristiwa kekerasan

2. Mereka yang ketakutan berjalan sendiri di malam hari Yaitu mereka yang percaya bahwa kehidupan nyata juga penuh dengan kekerasan, sehingga memunculkan ketakutan terhadap berbagai situasi yang memungkinkan terjadinya tindak kekerasan. Beberapa kajian menunjukkan bahwa untuk tipe ini lebih banyak perempuan daripada lakilaki.

3. Mereka yang terlibat dalam pelaksanaan hokum Yaitu mereka yang percaya bahwa masih cukup banyak orang yang tidak mau terlibat dalam tindakan kekerasan.

4. Mereka yang sudah kehilangan kepercayaan Yaitu mereka yang sudah apatis tidak percaya lagi dengan kemampuan hukum dan aparat yang ada dalam mengatasi berbagai tindakan kekerasan.

Kedua adalah penonton biasa (light viewers), yaitu mereka yang menonton televisi 2 jam atau kurang dalam setiap harinya. Kelompok penonton biasa (light viewers) memiliki sikap sebaliknya atinya tida begitu kuat pengaruh media terhadap mereka.

\section{Teori Agenda Setting}

Maxwell McCombs dan Donald Shaw,

Sebuah teori pengaturan genda, seperti yang awalnya dirumuskan pada tahun 1972 oleh Maxwell McCombs dan Donald Shaw, menjelaskan hubungan antara penekanan yang ditempatkan media massa pada isu-isu dan 
pentingnya khalayak media yang dikaitkan dengan isu-isu tersebut. gagasan bahwa media berkontribusi terhadap persepsi, nilai, dan prioritas audiens sebelum studi mereka. Dalam artikelnya "Fungsi Agenda-Pengaturan Media Massa," McCombs dan Shaw memberikan dukungan empiris untuk klaim bahwa prioritas media berita menjadi prioritas publik.

McCombs dan Shaw menyimpulkan bahwa ada hubungan yang kuat antara penekanan yang diberikan pada isu-isu oleh media (yaitu, agenda media) dan penilaian pemilih sendiri tentang arti-penting dan pentingnya masalah kampanye (yaitu, agenda publik). (Little John \& Foss 2009, 31), ini artinya bahwa masyarakat terpengaruh dari media tidak hanya tentang suatu masalah dan informasi yang disamapikan, tetapi juga seberapa penting informasi tersebut ditampikan oleh media.

Teori Agenda setting ini terinspirasi oleh kasus Watergate, yakni kasus pemilihan Presiden Nixon di Amerika tahun 1972. Maxwell McCombs dan Donald Shaw menganggap Watergate sebagai contoh sempurna dari fungsi pengaturan agenda media massa . McCombs dan Shaw percaya bahwa "media massa memiliki kemampuan untuk mentransfer arti-penting item-item pada agenda berita mereka ke agenda publik." Mereka tidak menyarankan bahwa redaksi siaran dan cetak melakukan upaya yang disengaja untuk mempengaruhi pendengar, pemirsa, atau opini pembaca tentang masalah tersebut. Sebagian besar wartawan di dunia bebas memiliki reputasi yang pantas untuk independensi dan keadilan. Tapi McCombs dan Shaw mengatakan bahwa kita mencari petunjuk profesional di mana kita harus memusatkan perhatian. "Kami menilai sama pentingnya dengan apa yang dinilai oleh media sama pentingnya." (Em Griffin,2012,379)
Model Agenda Setting

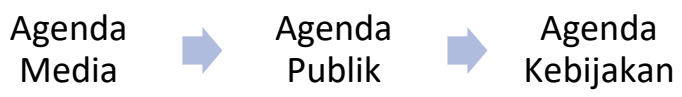

Sumber Em Griffin, 2012, 380

\section{Teori Ekologi}

Marshal McLuhan

Pada 1960-an, Marshall McLuhan adalah seorang profesor bahasa Inggris di University of Toronto. Dia meledak ke panggung publik dengan mengajukan pertanyaan tentang hubungan antara media dan budaya. Bukunya Understanding Media adalah kejutan yang menghasilkan kekaguman dan pertikaian. Teorinya menunjukkan bahwa media harus dipahami secara ekologis. Perubahan dalam teknologi mengubah lingkungan simbolik — dunia makna yang dibangun secara sosial dan sensoris yang pada gilirannya membentuk persepsi, pengalaman, sikap, dan perilaku kita.

Teori ekologi mengasumsikan bahwa pengaruh teknologi media terhadap masyarakat merupakan ide utama dibalik teori ekologi media. Adapun asumsi menurut teori ini antara lain:

1. Media melingkupi setiap tindakan dalam masyarakat.

2. Media memperbaiki persepsi masyarakat dan mengorganiasai pengalaman tersebut.

3. Media menyatukan seluruh dunia

Asumsi pertama menjelaskan bahwa masyarakat tidak dapat menghindar dari dari pengunaan media. Media hadir dalam kehidupan kita sehari hari. Media menurut McLuhan saat ini sudah menjadi kebutuhan pokok dalam kehidupan masyarakat. Asumsi kedua dijelsakan bahwa masyarakat secara langsung dipengaruhi oleh masyarakat. Menurut para ahli Ekologi media, Media 
memperbaiki persepsi masyarakat dan mengorganiasai pengalaman. Sebagai contoh menurut McLuhan, masyarakat setiap saat tanpa sadar- telah dimanipulasi oleh media setiap harinya. Asumsi ketiga dijelsakan bahwa media telah menghubungkan dengan seluruh kegiatan di dunia atau disebunya dengan desa dunia (global Village). Menurut McLuhan media telah mengikat dunia menjadi sebuah system sosial yang besar meliputi system politik ekonomi dan budaya yang ada saat ini.Media saat ini sudah menjadi jembatan dalah menghubungkan system social, budaya dan politik serta ekonomi yang ada di seluruh dunia. (West \& Turner, 2010, 430)

Teori McLuhan tentang ekologi media paling baik ditangkap dalam aforismenya yang terkenal, "Media adalah pesannya." Pernyataan penuh makna ini dimaksudkan untuk mengacaukan harapan kita. Kami terbiasa berpikir bahwa orang berubah karena pesan yang mereka konsumsi.Ketika McLuhan berkata, "media adalah pesannya," dia ingin kita melihat bahwa media — terlepas dari kontennya - membentuk kembali pengalaman manusia dan mengerahkan jauh lebih banyak perubahan di dunia kita daripada jumlah total pesan yang dikandungnya. (West \& Tuner, 2010, 433)

\section{Teori Spiral Keheningan}

\section{Elisabet Noelle-Neumann}

Teori Spiral of Silence berpendapat bahwa opini publik adalah kekuatan yang kuat dalam masyarakat kontemporer dan menjelaskan peran media massa dalam berkontribusi pada — dan bahkan memperbesar - efek dari kekuatan itu. Menurut Noelle-Neumann ada tida assumsi yang ada dalam teori ini pertama masyarakat mengacam individu-individu yang menyimpang dengan adanya isolasi, rasa takut terhadap isolasi sangat berkuasa. Kedua Rasa takut akan isolasi menyebabkan individuindividu untuk setiap saat mencoba menilai iklim opini. Ketiga Perilakuk public dipengaruhi oleh penilaiaan akan opini public. (West \& Tunner 2010, 414)

Lebih jelasnya, Teori Spiral of Silence berpendapat bahwa individu merasakan tekanan untuk menyembunyikan pendapat mereka ketika mereka merasa bahwa pandangan tersebut berada di minoritas atau di luar arus utama. Pada saat yang sama, individu akan lebih bebas mengekspresikan pendapat mereka ketika mereka merasa bahwa mereka mewakili sudut pandang mayoritas. Karena media massa berulang kali memberi isyarat kepada anggota masyarakat yang pandangannya dapat diterima dan mana yang tidak, efek spiral dihasilkan: Pandangan mayoritas dibuat tampak lebih dominan daripada yang sebenarnya — berkat liputan media yang terus-menerus dan implisit atau eksplisitnya. dukungan - sementara pandangan minoritas dibuat tampak lebih tidak populer atau lebih jauh dari arus utama daripada yang sebenarnya terjadi, karena kecenderungan media untuk memarginalkan atau bahkan mengabaikannya sama sekali. Akibatnya, khalayak media massa akan semakin terdorong untuk mengutarakan pendapat mereka jika pandangan mereka sesuai dengan pendapat yang disampaikan oleh media sebagai yang mayoritas atau untuk tetap diam jika pandangan mereka adalah pandangan media yang meremehkan, memarginalkan, atau mengkritik. Karena pandangan tertentu diberikan lebih banyak suara dalam masyarakat dan yang lain kurang, media mengambil polarisasi ini dan memperbesarnya.

Sebagai hasil dari pola komunikasi individual ini, media memperdalam prosesnya ke tingkat yang lebih besar, memberikan keunggulan yang semakin besar pada 
pandangan mayoritas sambil mengurangi pandangan minoritas menjadi tidak penting atau tidak terlihat, dan seterusnya, dan seterusnya. Spiral terus berputar sampai pandangan minoritas akhirnya hilang dari media dan ekspresi individu, dan pandangan mayoritas menjadi satu-satunya yang dianggap dapat diterima. Pada akhirnya, kemudian, opini publik (dan penguatannya oleh media) berfungsi tidak hanya untuk mencerminkan, tetapi juga untuk membentuk sikap dan tindakan masyarakat.

Media massa berkontribusi pada dan melebih-lebihkan — persepsi tentang kuasi-statistik organ kita, khususnya dalam masyarakat industri kontemporer. Dengan demikian, bahkan ketika kita membuat bacaan kita sendiri tentang pandangan masyarakat, persepsi pribadi kita hanya berkontribusi sebagian terhadap rasa opini publik kita. Alihalih, media massa, kekuatan dominan dalam kehidupan pribadi kita dan budaya kita bersama, berkontribusi lebih signifikan lagi pada persepsi kita tentang sikap terhadap opini publik. Ini terjadi karena media ada di manamana, karena mereka hanya mengekspresikan atau mengesahkan berbagai pendapat dan sudut pandang yang sangat terbatas, dan karena mereka terus-menerus mengulangi konten mereka yang sempit; sebagai hasilnya, mereka cenderung memperbesar perbedaan antara berbagai segmen masyarakat

Dalam gambar dibawah ini dijelaskan opini public sebagaimana dikomunikasikan oleh media.

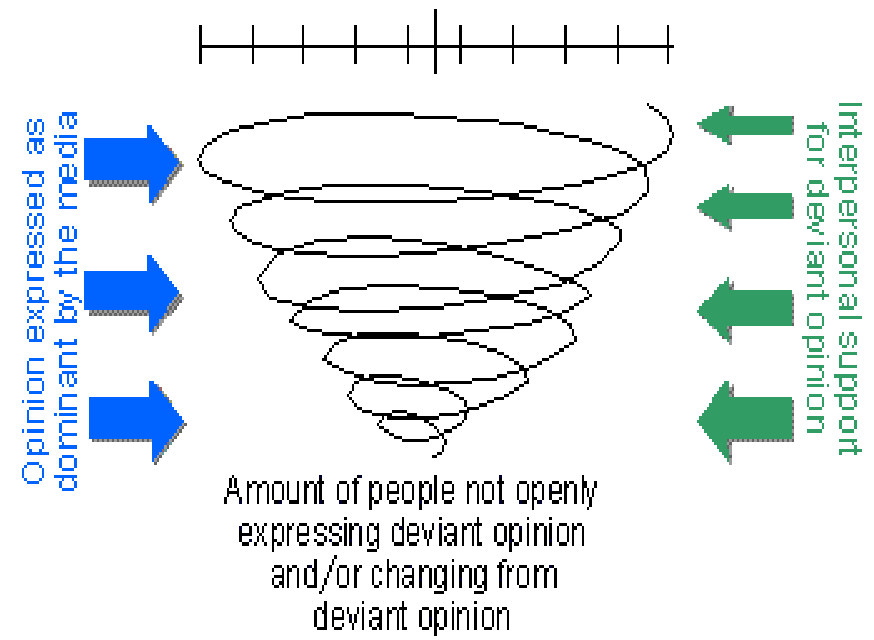

Noelle-Neumatit's Spiral of Silence

Sumber, West \& Tuner 2007

\section{Pembahasan}

Perkembangan teori efek media dimulai dengan perkembangan teknologi media yang ada di dunia. Perkembangan efek media telah dimulai pada fase media cetak yang diawali dengan penemuan kertas di China serta penemuan mesin cetak di Eropa. Namun pada awa mulanya tidak banyak teori yang lebih menekankan pada efek media. Namun ada beberapa peneliti yang mencoba meneliti efek media yang kemudian menghasilkan beberapa teori. Teori tersebut antara lain Teori Stimulus-Respon dari Melvin Defluer, dan Teori Opini Umum dari Walter Lippman serta beberap teori lainya.

Selanjutnya perkembangan teori efek media ini dilajutkan dengan perkembangan teknologi media pada face penyiaran (broadcasting) yakni berupa audio dalam bentuk radio dan audio-visual dalam bentuk televisi. Inilah awal banyaknya penelitian efek media yang dilakukan. Penelitian tersebut dimulai dengan hysteria massa di Amerika efek dari siaran radio pada tahun 1938. Fenomena tersebut memulai pesatnya penelitian efek media sehingga menghasilkan 
beberapa teori yang sangat berguna bagi ilmu komunikasi.

Penelitan efek media tersebut banyak dipengaruhi oleh prilaku masyarakat baik secara individu maupun secara kelompok. Perubahan perilakukan akibat perkembangan teknologi media komunikasi juga menambah khasanah perkembangan teori efek media yang ada selama ini.

Penelitian pada sejarah dan peradapan teori efek media telah cukup berkembang sampai pada tingkatan beberapa sub area khusus penelitian. Peneliti bisa melihat studi tentang efek media misalnya tentang kejahatan, kekerasan, dan agresi; pendidikan media, edutainment (hiburan yang memiliki elemen atau fungsi pendidikan untuk itu); pornografi; bujukan; stereotip dan sosialisasi media; difusi agenda politik; banding media dan ketakutan; dan dampak teknologi media baru, telah begitu cepat perkembangan akhirakhir ini.

\section{Simpulan Dan Saran}

Sejarah dan perkembangan teori efek media lebih banyak dipengaruhi oleh perkembangan teknologi media dan perubahan perilaku masyarakat akibat terpaan media.. Beberapa perkembangan teknologi yang dibuat menyebabkan perilaku masyarakat baik secara individu maupun kelompok atau komunitas tertentu. Perubahan perilaku inilah yang kemudian diteliti oleh para ahli guna menciptakan teori efek media yang ada saat ini. Perkembangan paradigma media efek diteliti berdasarkan perubahan perilaku yangada pada masa tersebut

Beberapa teori efek media tidak lagi relevan digunakan, namun sebagai pijakan atau referensi yang baik bagi penelitian lanjutan. Seiring dengan perkembangan teknologi internet, beberapa teori efek media masih bisa digunakan guna menjawab fenomena yang terjadi pada saat ini. Namun perlu penelitian lanjutan guna menlihat efektifitas teori efek ini pada media internet atau media social yang ada.

Sampai saat ini penelitian teori media efek ini masih terus menjadi topik yang menarik dan terus dikembangkan. Mudah mudahan aka nada penelitian lanjutan dalam penulisan media efek ini.

\section{Daftar Pustaka}

Alan M. Rubin, "Uses-And-Gratifications Perspective on Media Effects," in Media Effects: Advances in Theory and Research, editon 3., Jennings Bryant and Mary Beth Oliver (eds.), Lawrence Erlbaum, New York, 2009, pp. 165-184.

Ball-Rokeach, S. J., Y. C. Kim dan S. Matei. (2001) "Storytelling Neighborhood: Paths to Belonging in Diverse Urban Environment." Communication Research.

Defleur, M.L., dan S. Ball Rokeach. 1975. Theories of Mass Communication, 3th ed. New York: David McKay.

Elihu Katz, Jay G. Blumler, \& Michael Gurevitch. (1973). Uses and gratifications research. Public Opinion Quarterly, 37, 509-523.

Elihu Katz, Jay G. Blumler, and Michael Gurevitch, "Utilization of Mass Communication by the Individual," in The Uses of Mass Communications: Current Perspectives on Gratifications Research, Sage, Beverly Hills, CA, 1974, pp. 19-32.

Em Griffin (2012), A First Look At Communication Theory Published by McGraw-Hill Education, 2 Penn Plaza, New York, NY 10121.

Gerbner, G. (1970). Cultural indicators: The case of violence in television drama., 
Annals of the American Academy of Political and Social Science, Vol. 388, Political Intelligence for America's Future. (Mar., 1970), pp. 69-81.

Hetsroni, A. (2008). Overrepresented topics, underrepresented topics, and the cultivation effect. Communication Research Reports, Vol.25, 200-210.

Hetsroni, A., Elphariach, H., Kapuza, R., \& Tsfoni, B. (2007). Geographical proximity, cultural imperialism, and the cultivation effect. Communication Monographs, 74, 181-199.

Jeffres, L., Neuendorf, K., Bracken, C., \& Atkin, D. (2008). Integrating theoretical traditions in media effects: Using third-person effects to link agenda-setting and cultivation. Mass Communication \& Society, 11, 470491.

Lazarsfeld, P. F., Berelson, B., \& Gaudet, H. (1948). The people's choice: How the voter makes up his mind in a presidential campaign. New York: Columbia University Press.

Littlejohn \& Foss, (2009) Enclyclopedia of Communicaton Theory, SAGE Publications, Inc.

McCombs, M. E., \& Shaw, D. L. (1972). The agenda- setting function of mass media. Public Opinion Quarterly, 36, 176-187.

McLeod, J. M, \& Reeves, B. (1980). On the nature of media effects. In $\mathrm{S}$. B. Withey \& R. P. Abeles (Eds.), Television and social behavior: Beyond violence and children (pp. 1754). Hillsdale, NJ: Lawrence Erlbaum.
Mohd. Rafiq, Dependenci Theory, Jurnal Hikmah, Vol. VI, No. 01 Januari 2012, 01-13.

Nabi, R., \& Clark, S. (2008). Exploring the limits of social cognitive theory: Why negatively reinforced behaviors on TV may be modeled anyway. Journal of Communication, 58, 407-427.

Niederdeppe, J. (2008). Beyond knowledge gaps: Examining socioeconomic differences in response to cancer news. Human Communication Research, 34, 423-447.

Noelle-Neumann, E. (1974). The spiral of silence: a theory of public opinion. Journal of Communication, 24, 43-51.

Scharrer, E. (2008). Media exposure and sensitivity to violence in news reports: Evidence of desensitization? Journalism \& Mass Communication Quarterly, 85, 291-310.

Servin, Werner J. 2005, Communication theories : origins methods use New York : Hastings House 1979.

Sparks, G. G. (2002). Media effects research: A basic overview. Belmont, CA: Wadsworth.

West, R \& Tuner, Lynn (2010), Introduction Communication Theory; Analysis and Aplication, McGraw-Hill Companies Inc 